\title{
EXTERNAL DEBT AND EXPORT PERFORMANCE IN PAKISTAN: AN EMPIRICAL INVESTIGATION
}

\author{
Muhammad Asif Shamim \\ Assistant Professor, Bahria University, Karachi, Pakistan \\ Syed Tehseen Jawaid \\ Assistant Professor, Bahria University, Karachi, Pakistan \\ Madiha Kamal \\ PhD Scholar Applied Economics Research Centre, University of Karachi a
}

\begin{abstract}
The objective of this research is to study the relationships between the two variables, external debt and exports performance within the reach of Pakistan. The data used for the study was selected by annual time series from 1972 to 2014. According to the co-integration analysis done for the study there was a significant negative relationship between export performance and external debt in Pakistan. Whereas when the Error correction model was used, the results pointed out an inconsequential relationship in short run within the two variables, external debt and exports in the short run. The next test of stability analysis confirms that long run model is stable whereas, the granger causality test claims an unidirectional relationship from external debt and exports; the result of impulse response also confirms the negative relationship between exports and external debt in Pakistan; further the result of FMOLS states that the initial results are vigorous; the major reasons for the negative link between the two variables exports and external debt is the IMF conditionality to Pakistan that it has to raise revenue by increasing indirect taxes and increasing energy prices. It is suggested that dependency on external debt should be discouraged and this gap of foreign inflow should be covered with foreign direct investment and inflows of workers' remittances and by increasing export earnings in the country. Government should improve the regional trade agreement and should avail the opportunity of GSP plus (Generalized Scheme of Preferences) status by improving the law and order situation. It is also suggested that government should control the failure of power supply and export allowances should be given to the Export Processing Zones. These are the earliest measure that should be taken to minimize the negative effects of external debt on export performance in the country.
\end{abstract}

Keywords: Export, External Debt, Pakistan, Time Series Analysis.

\section{Jel Classification:C62, C68,C69}

*The material presented by the author does not necessarily portray the view point of the editors and the management of the Ilma University - Formerly IBT

1 Muhammad Asif Shamim:

asifshamim.bukc@bahria.edu.pk

2. Syed Tehseen Jawaid:

3. Madiha Kamal:

stjawaid@hotmail.com

madihakamal@live.com

OILMA-JBS is published by the Ilma University - Formerly IBT

Main Ibrahim Hydri Road, Korangi Creek, Karachi-75190, Pakistan. 


\section{INTRODUCTION}

The External Debt Statistics Working Group was established in year of 1984 jointly by 4 different financial bodies including IMF (International Monetary Fund). BIS that is Bank for International Settlements, WB that is World Bank, and OECD that is Organization for Economic Cooperation and Development. The External Debt Statistics working group has basically proposed the main definition for external debt in year of 1988 (Klein, 1994:56). Within any organization or government body, the term Debt is claimed as the capital resource or money in current financial cycle, which is not initially supplied by the investors or the CEOs (Oyejide 1985).

Many factors in an economy are responsible for effecting the economic growth of the concerned region. However, External debt play both, negative and positive role in a developing country. There can be positive or negative effects of external debts on the performance of export mainly relying on the uses of debt; either it is uses in export oriented firm or not. External debt is beneficial in terms of developing a country that is they can be utilized different projects which are investment oriented including the infrastructure projects, power points or any projects in the agricultural industry. As far as usage of external debt at a low level is concerned, the studies have showed that they do have positive effects on the socio-economic development of any nation, but debt have negative effects if it is utilized on a greater margin. In other words, if debt is used at a higher margin than the relationship of economic growth in any country with reference to the external debt can turn negative.

The turning points for debt gross domestic products is said to be specifically around 35 to 40 percent whereas the export debt ratio is 160 to 170 percent approximately. If the external debt is used for private and public use it may affect negatively and therefore it would not give any return to the firm.

We can observe a positive connection between the free trade in Pakistan and the foreign debt as the increase in the trend of trade openness is spread it outstretch the external debt in Pakistan (Zakaria 2012). Only domestic debt impacts growth while foreign debt does not and vice-versa.(Audu and Abula 2001); In this situation the government bodies of a country borrows the money to cover the gap between the investments and saving so that the resource gap is covered effectively (Likita 2000).

There have been many studies that have improvised the overall growth of any country which is specifically led by the exports sector by adding more than one macroeconomic variable in their current research model. Such as in a research study concluded by Sheehey (1990), Jones (1989) concluded the results of a test that were based on the test which aim was to study the relationship of different variables including the three main as economic external debt servicing growth and exports. Some other variables introduced by different researchers included foreign loan (Amoateng and Adu, 1996) imports (Din, 2004) as well as global revenue (Afzal, 2006).

Theoretical evidence of exterior loan is described in the study of (Karlmax1883) briefly. The researcher explains the external debt cost in the waste of labor, hence it causes redundancy. Therefore this domino effect in the central banks that accepted rights in return for giving loan to state. It situation boosts more level of taxes so that the national debt can be paid.

According to the study conducted by (RudgerDombush and Stanley Fisher 1978) the term National loan is associated with the budget surplus and deficits, with the budget deficit 
national dent increases and vice versa. It is also indicated that the link among the variables, foreign loan and the growth is negative. (Adam Smith 1776) describes three traits of external debt namely; government spending, disapproval of growing taxes and inclination of capitalist to lend.

As we understand that Export is used as an instrument to stimulate the overall growth of an economy, therefore the returns of the factor of production are boosted. Exports even are known for adding more scope for the opportunities of investment in any economy, which later results in increased savings and income in many sectors of any economy. The foreign investment also acts as a catalyst and reduces many socio-economic issues in the county by providing more hob opportunities and healthy competition.

Considering the economy of Pakistan, the economics condition in the country has gone through many difficulties due to the political and economic ups and downs in the country since 1070's.

Since 1970 this economic conditions have been effecting the growth of Pakistan internally and externally as well. Therefore the internal and the external debts are considered as the root source of the major problems in the economies which are causing these dilemmas since 1980. Moreover in the year 1990, the revenue of the government was even less than their total expenditure, and due to this the fiscal deficits were observed. These deficits were confined by the external and internal borrowing from different sources.

Initially, the inflow from the external debt may provide some easy. Meanwhile, higher fiscal imbalances, inadequate use of those inflows can lead to higher level of external debt stock. The debts adversely affect the economy as it discourages investments, production and export as well. Furthermore, it devaluates the currency and the consequences were a higher number of import bills. Therefore, it is very important to understand the degree of correlation of the variable growth with the debt service liabilities. We need to determine the sources suitable for a country with the use of correct methodology and econometric techniques, in order to minimize the varying impact on the aggregated investment.

In Pakistan, external debt has played a negative role because of the other problems affecting the economy Pakistan on whole. In case of External debt in Pakistan, the facts starts that they have grown from $\$ 19.2$ bn in the year 1990 to $\$ 33.60$ bn in the year 1999 with in the span of 9 years and further to $\$ 37.362$ billion by 2007 and 62.184 billion in 2014in the next 7 years. Reevaluation of the manner in which the external debts are managed should take place and that will not only be followed by the economy would be out of crises, but the economy will also flourish and its export aspect would also be increased, as it's the source of foreign exchange as well.

Pakistan spends its $65 \%$ of its income on financing debt servicing and leaving just $35 \%$ of its income on defense and development undertakings, for example, education and wellbeing.

Pakistan on external front spends around 6-7 billion dollars on the debt servicing from a cumulative 11-12 billion dollars of foreign exchange. And this leaves an amount of 5 billion dollar to hold imports of 7-9 billion dollars. In order to increase the saving funds, legislature, the loan fee is set high, causing the private investors to bail out from the economy. Thus in the year 1990 the cumulative investment was declining, causing a major decline in the main economic activity in the country. 
At the point when Musharraf's administration assumed control, it tackled numerous issues and found a way to combat the issue of external debt, which even included "the debt limitation law", although it was aimed to manage diminish the weight of external debt and limit the borrowing.. Moreover after the major issue of 9/11 Pakistan as a state was declared as a state of terror. Not only this but the overall strategies and business operations were changed drastically after the 9/11 event including the remittance and the foreign grants which decreased significantly. Thus Pakistan paid the debt services and the interest amount of the WB and IMF.

\subsection{Motivation of the study}

On the basis of the above discussion it is concluded that Most of the studies have analyzed the external debt and trade, external debt and growth, external debt and trade openness. There have been no significant studies conducted within the geographical location of Pakistan on relationship of the Export and external debt. Hence, the research would be of great help for other researchers and business analyst to analyze the current economic stands of Pakistan.

\subsection{Objective}

The objective of this study is to assess the influence on Export Performance of Pakistan by foreign loan for the period 1972-2014. Next session will be discussed theoretical and empirical study after that the Information and procedures and afterward Findings of the estimations are reported and discussed. At the end deals with concluding remarks and some recommendations based upon the previous and current study and will be highlighted some areas for further studies.

\section{LITERATURE REVIEW}

\subsection{Theoretical Framework}

At the point when borrowers have an alternative to revoke their debt, the collaborations of borrowers and loan specialists after some time exhibits a key circumstance of gigantic multifaceted nature. Think about the instance of a sovereign getting nation, increasing advances using the global capital business sector. Following Eaton and Gersovitz (1981) assume that denial of the debt produces budgetary autarky and lost beneficial productivity of the nation that is unable to pay its debt. Any nation that is in-debt, must adjust the expenses with immediate reimbursement of debt, following the choice of refutation. As a result, loan provider will opt credit rationing to reduce the exposure to a very low level that is sufficient enough to render debt repudiation an inferior option to the country that borrows.

The procedure of distribution of credit is difficult to figure. The basic point is to give advance to the level where the nation is inert between debt reimbursement and renouncement. One of the advantages for debt reimbursement on time is an open alternative to acquire more advances again later on. Be that as it may, the decision is absolutely reliant on the sum required later on by the credit seeker. That will be subject to the banks' evaluation in eventual fate of the purpose of lethargy of the advance looking for nation related to reimbursement and nullification. It will rely on upon the capacity of the nation to get in the far off future. 


\subsection{Empirical Framework}

Countless research has been conducted in order to study the relationship between growth and foreign loan, foreign loan and export, external debt and trade etc. These researches concluded varied results regarding the relationship between both the variables as discussed below:

Zafer et al (2015) analyze the influence of free trade and foreign loan on socio-economic development. Panel regression technique has been utilized; the study has been directed between three distinct regions which are partitioned by World Bank (1980 to 2012). The outcomes indicate a positive connection between organized commerce and advancement. Besides, outside obligation has vital and adverse effect on financial development and obligation as seen by the nations as a duty and weight on the economy.

Ali (2014) examines the effects of Foreign Direct Investment (FDI), external debt remittances on socio-economic development in Pakistan. Johansen co-integration technique and Granger causality test has been applied for the study for the selected period of 1972-2013. The outcomes demonstrate the unfriendly impacts of these streams on the improvement of the economy in a more drawn out run. Short run focus on revealed unidirectional causality running from commitment advantage, FDI, swelling and instruction rate to headway. Causality from domestic wander is not completed yet rather it moves from improvement to domestic theory. Bidirectional causality among settlements and change has been viewed. The study endorses a couple approaches, for instance, domestic resource readiness, infrastructural progression, fiscal advancement, sensible macroeconomic steps for reliability of trade and change out work drive for a whole deal money related change.

Dritsaki (2013) analyzes the relationship between socio-economic advancement, exports and government's loan of Greece for the time period 1960-2011.Vector error correction models (VECM) and Granger causality test are utilized to watch the nearness of causality between those factors. The outcomes demonstrate that short term and long term haul connections win among these factors. Impressively, the outcomes demonstrate that there is a unidirectional causality that moves from exports to financial development and also from monetary development to government debt, though there is no short-term causal relationship among government debt and national exports. In a long keep running, there is a unidirectional causality that moves from government debt to monetary development.

Abdullahi et.al (2013) analyses the connections among economic growth and external debt in Nigeria, using time period data for time period 1970 - 2009. Outcomes reveal that there is no short term connection between economic advancement and foreign loan but in the long duration in Nigeria.

Kasidi et al (2013) study the effects of economic development and external liability of Tanzania using time series for 20 years (1990-2010) study using the time series data on liability and country's performance. The study uncovered that there exists a noteworthy effect of liability administration and foreign liability on GDP development. The aggregate outside liability has a useful impact and loan benefit installment have an antagonistic effect. The study uncovered that there exists a noteworthy effect of the loan administration and outer loan on GDP development. There does not exist any long term connection of the GDP and other loan.

Umaru et al (2013) studies the effects of domestic loan and foreign liability on the development of the Nigerian Economy using time period from 1970 to 2010 using economic 
growth as dependent variables and domestic loan, external liability as independent variables. Augmented Dickey Fuller technique in analyzing the unit root property of the arrangement and Granger causality trial of causation between GDP, outside liability and domestic loan show that every one of the factors in the model are stationary and the outcomes of causality demonstrate that there is a bi-directional causation existed amongst GDP and outer debt, while no causation was found amongst GDP and internal loans and additionally no causation is seen between domestic loan and outside liability. It is suggested that the legislature must devise arrangements protested at empowering domestic reserve funds in correlation with domestic venture.

Atique et al (2012) observed the effects of External and internal loans on the Economic Development of Pakistan using time period from 1980 to 2010 using real gross domestic product growth as dependent variable and corruption, human capital, inflation, net total investment, external debt and domestic debt are the independent variables. Ordinary Least Square (OLS) approach is used for Co-integration, Serial Correlation Testing, Unit Root Testing, test for checking Heteroskedasticity and CUSUM test of stability. Results propose a negative relationship between GDP growth rate and domestic debt and further showed inverse relationship between loans and GDP rate. External debt amount reduces the rate of economic growth more when compared with domestic liability amount. An adverse impact of external debt is very prominent on the economic development as compared with the domestic debt. It is suggested that the government of Pakistan must devise new strategies for debt management.

Saad (2012) investigate the causality between economic development, foreign loans and exports of Lebanon, using the time series data of 40 years (1970-2010), vector error correction model, Granger causality technique has been used. GDP, external debt, export and exchange rate has been used; exchange rate is used as new variable. The exports were acquainted in the model with test the fare drove development theory for Lebanon .The outcomes demonstrates that the fleeting and long haul both connections exist among those factors. It is recommended that if exports result in the financial development then the achievement of a predetermined level of development might be an essential for the nation to expand its exports.

Checherita and Rother (2012) examine the average effect of government debt on per-capita GDP growth in twelve European countries over a period from 1970 to 2009. The dependent variable is the financial development rate and the free factors are sovereign long haul loan fees and Public debt. In this paper likewise depicts the channels private sparing, open speculation; add up to total factor productivity (TFP) and sovereign long haul ostensible and genuine loan fees that how does outer debt impact on financial development. The outcome demonstrates the general population debt proportion and the spending shortfall to-GDP proportions are contrarily and directly connected with per-capita GDP development.

Gohar (2012) study the relationship between GDP and other variables such as foreign loan servicing, savings, interest rates, Foreign Direct Investments and net exports of the country. Annual panel data was collected from 1990 to 2008. The sample of 36 low income countries are taken .Least square multiple regression method has been used. Results show that the external debt servicing impacts the growth and export adversely.

Ali and Mustafa (2012) analyze the foreign loan buildup and its effect on monetary growth in Pakistan using time series of data from 1970 to2010, study use comprehensive fabrication purpose for gross national product as a role on yearly education spending, assets work 
strength and external debt as a percentage of GDP. Co-integartin and ECM technique has been utilized to gauges the transient and the long haul relationship between the factors. Comes about showed that outside debt practices huge unfriendly effect on monetary development both in the short and the long haul. The headcount impacts GNP unfavorably impacts in the long haul and in the short term. Be that as it may, the effect in the transient is not that much. It demonstrates that human asset and capital adds emphatically and altogether to GNP in the long haul and the short term.

Kizilgol and Ipek (2012) analyze the empirical association between trade directness and external debt for Turkey's economy, through the use of time series data from the year 19702008. ARDL and GMM technique has been used .Results indicates that an increase in trade openness has a positive impact on external debt both in the short run as well as in the long run.

Afzal et.al (2010) studies the fundamental nexus among financial enlargement, export and foreign loan servicing the case of Pakistan from the time period of 1970 to 2008 using economic growth, exports and foreign loan servicing variables. They used vector error alteration models (VECM) and augmented vector autoregressive (VAR) method. The experiential results propose that the long term and the short term stable state live among three variables, while unidirectional Granger causality exist between (i) GDP and export that runs from GDP to export and support the growth-driven exports hypothesis.(ii) Debt servicing and GDP that moves from Debt servicing to GDP.

Afzal et al (2008) studied the relationship between economic growth, exports and foreign loan servicing of Pakistan. Data from 1970-71 to 2007-08 has been used .Vector error correction models (VECM).Augmented Vector autoregressive (VAR) and Toda Yamamoto techniques has been used. The results propose that the short term as well as long term persistent state prevail between exports, growth and foreign loan servicing of Pakistan. Unidirectional causality exists between GDP and exports.

Shabbir (2008) does exterior debt involve economic growth: verification from rising countries using data from 1976 to 2003 using rate of GDP and GDP as reliant variable and external debt servicing as self-governing variable, the outcome propose an inverse relationship between load of outside debt to GDP proportion and the GDP development rate in creating nations anyway they prescribed that the creating nations to channelize their outer capital in a strategy that it can help with making new open doors for venture and attract more financial specialists to their nation .

Panizza (2008) studied the relationship between domestic and outside civic debt in developing countries using time series data from 1994 to 2006 using outside debt and domestic debt as variables. It is studied that the possible transactions amidst local and foreign liabilities and points out that while the steps towards more local loans can play a constructive function in plummeting the risks of sovereign finance, policymakers should not be too selfsatisfied.

Schclarek (2004) investigates the Debt and Economic Growth in Developing and Industrial Countries using time series data from 1970 to 2002 using the TFP growth rate, the growth rate of GDP per capita, the capital accumulation growth rate per capita, and the private savings rate as dependent variables and Foreign loan; Public debt as an independent variables. The results reveal that for developing countries there is an adverse but prominent relationship between total foreign loans and economic growth. 
Karagol (2002) investigate the impact of External Debt Service on GNP the Case of Turkey. It is squabble that unpaid debts repair load unenthusiastically affects resource and capital development. The primary reason is that the better extent of treasury (outside money) goes to meet debt redesign and there will be a diminishment in outer capital due to a reduction in credit value .Multivariate co-joining techniques and vector blunder remedy show has been utilized.

Ahmed et al (2000) develops a multivariate co integration and error correction model to test the causality among exports, economic growth, and foreign debt servicing in 8 Asian countries for the period from 1970 to 1997.The outcomes demonstrates that no long-run adjust affiliation exists among the pertinent time-arrangement, with prominent special cases for Bangladesh and Indonesia. These outcomes, all in all, give powerless support to a cocoordination relationship between exports, monetary development, and remote debt adjusting among a few Asian nations, including Pakistan. The ECM is tried for Bangladesh and Indonesia, for which a co-incorporating connection between the causal variables can't be rejected. The experiential results don't give evidence that the monetary development in being significantly overstated either by the fare continues development or by the joint exertion of exports and remote debt in the South and South-East Asian nations between 1970 and 1997. The outcome inferred that for Bangladesh, development of outer debt brings about lower send out income development, and remote debt overhauling had all the earmarks of being adversely influencing the fare development relationship in this poor nation. Prove for residual nations neither backing the theory of fare drove development nor the GDP development driven exports speculation in the 1971-97 periods. This show, neither outside credit nor IMFdrove basic projects applies any critical crash on the money related development in these nations in the 1971-1997 periods. Or maybe, it infers that for these nations development of outer debt brings about bringing down both financial development and fare income development.

\section{MODELING FRAMEWORK}

The model to estimate the effect of external debt on the exports of Pakistan is defined below:

$$
\text { EXP }=\beta_{0}+\beta_{1} L(R G D P)+\beta_{2} L(R E R)+\beta_{3} L(E X D)+C i
$$

Where; EXP is export (Yousuf et al 2008 ,Frnasco 2012 ,Mekki 2005, Clements et al 2003, dogruel and dogruel 2006), RGDP is of Real GDP (Yousuf et al 2008 ,Clements et al 2003 , Ertugrue and Kenar 2012) RER is the real exchange rate(Yousuf et al 2008, Tang and Lai 2011) and EXD is the external debt(Clements et al 2003). In the mentioned condition the coefficient of RGDP and RER are required to be positive, however the coefficient of EXD is to be calculated. Annual time series data has been utilized to discover the effect of EXD on Export performance from 1972 to 2014. The information of this study is collected from the distinctive issues of the Pakistan economic survey. All variables are utilized as a part of logarithmic form. To examine the information diverse measurable tests have been utilized for checking the relationship and responsiveness. In this analysis, the Augmented Dickey Fuller (ADF) statistics, Phillips-Perrontest, Cointegration Test, ARDL bound test, ECM test Eagle and Granger (1987) residual based test the Trace test and the Maximum Eigenvalue test, Causality Analysis, stability analysis test, sensitivity analysis test and impulse response techniques are used. 


\section{ESTIMATION AND RESULTS}

As for preliminary stationary analyses, the combination properties of the data are checked by utilizing traditional unit root tests. On account of the presumable structural breaks in the series, unit roots were performed utilizing the Phillips-Perron (PP) technique, and the Augmented Dickey Fuller (ADF) statistics. Distinct to the ADF test, the PP test checks the likelihood of pattern non stationary emerging from external shocks and other sources of structural instability, which may have happened in the nation in the period under examination.

Unit root tests for stationary were performed on both levels and first differences for all variables to be utilized as a part of the essential and amplified model. Two distinct models have been considered while performing tests. The model with constant $(\mathrm{C})$ expects that there are no patterns in the levels of the data, such that difference series has zero mean. While the model with a constant $(\mathrm{C})$ and linear pattern $(\mathrm{T})$ is utilized when linear trend as a part of the levels of the data are observed. The results of the unit root tests are stated in Table-1.

Table 1: Stationary Test Results

\begin{tabular}{|c|c|c|c|c|c|c|c|c|}
\hline \multirow{3}{*}{ Variables } & \multicolumn{4}{|c|}{ Augmedted Dickey-Fuller } & \multicolumn{4}{|c|}{ Phillins-Perron } \\
\hline & \multicolumn{2}{|l|}{ I(0) } & \multicolumn{2}{|l|}{ I(1) } & \multicolumn{2}{|l|}{ I(0) } & \multicolumn{2}{|l|}{ I(1) } \\
\hline & $\mathbf{C}$ & C\&T & $\mathbf{C}$ & C\&T & $\mathbf{C}$ & C\&T & $\mathbf{C}$ & C\&T \\
\hline EXD & 0.287 & 0.336 & 0.001 & 0.002 & 0.530 & 0.378 & 0.000 & 0.000 \\
\hline EXP & 0.782 & 0.639 & 0.000 & 0.000 & 0.782 & 0.557 & 0.000 & 0.000 \\
\hline GDP & 0.380 & 0.931 & 0.001 & 0.003 & $\begin{array}{l}0.014 \\
5\end{array}$ & $\begin{array}{l}0.093 \\
9\end{array}$ & 0.001 & 0.003 \\
\hline RER & 0.533 & 0.128 & 0.000 & 0.000 & 0.504 & 0.106 & 0.000 & 0.000 \\
\hline
\end{tabular}

Note: Note: The significant values for PP \&ADF tests with constant and trend (C\&T) and with constant (C) at 1\%,5\% and $10 \%$ level of significance are -3.711, $2.981,-2.629$ and $-4.394,-3.612,-3.243$ respectively.

Source: Authors' estimation.

The unit root-test is used to examine stationarity in the series. The above mentioned table presents the analysis of stationarity test. The 'A.D.F.' test analysis reveal all the variable are not stationary at level and are stationary at first-difference which indicates that JJ Cointegration test (table-2) is valid to determine long-run affiliation while the PP-test statistics found that few variables to be stationary at the level, therefore to justify the long-run relationship the ARDL test (table -3) has been performed.

Table -2 shows results of J.J integration and table-3 presents the outcomes of ARDL cointegration test.

Table- 2:J.J Co-integration Test Results.

\begin{tabular}{|l|l|l|l|l|}
\hline $\begin{array}{l}\text { Hypothesis } \\
\text { No. of CE(s) }\end{array}$ & $\begin{array}{l}\text { Trace } \\
\text { statistics }\end{array}$ & $\begin{array}{l}\mathbf{5 \%} \text { critical } \\
\text { values }\end{array}$ & $\begin{array}{l}\text { Max. Eigen } \\
\text { value } \\
\text { statistics }\end{array}$ & $\begin{array}{l}\text { 5\% critical } \\
\text { values }\end{array}$ \\
\hline None & 52.696 & 47.85 & 29.024 & 27.58 \\
\hline At Most 1 & 25.67 & 29.797 & 17.702 & 21.131 \\
\hline
\end{tabular}


Journal of Business Studies - JBS Vol.13 Issue.2, December 2017

\begin{tabular}{|l|l|l|l|l|}
\hline At Most 2 & 1.166 & 3.841 & 6.803 & 14.264 \\
\hline
\end{tabular}

Source: Authors' Estimations.

Table -3: Lag Length Selection \& Bound Testing for Cointegration (ARDL)

\begin{tabular}{|c|c|c|c|}
\hline Lags Order & AIC & SBC & F-test Statistics \\
\hline 0 & -2.825 & -2.656 & \multirow{4}{*}{$11.120 *$} \\
\hline 1 & -11.358 & $-10.514^{*}$ & \\
\hline 2 & $-11.699 *$ & -10.179 & \\
\hline 3 & -11.286 & -9.090 & \\
\hline
\end{tabular}

Source: Authors' estimation.

Note :

(1) $\quad * 1 \%$ level of significant.

(2) AIC: Akaike information criterion; SBC: Schwarz Bayesian criterion.

Johansen and Juselius (1990) co-integration method is used to study the long term relationship between the variables. Two test statistics have been derived for co-integration namely Trace Statistics and Maximum Eigen value statistics. The calculated trace and Maximum Eigen Values statistics and their parallel critical values can be seen in the above table

The ARDL reveal that the rejection of null hypothesis of no co-integration in the model because F-statistic value exceeds the upper bound critical value at $1 \%$ significance level. Therefore the long term relationship exists between the variables.

Table -4: Long run Determinants of Aggregate Export.

\begin{tabular}{|l|l|l|l|}
\hline Variables & Coefficient & t-statistics & Prob. \\
\hline Constant & -4.44 & -7.04 & 0.000 \\
\hline GDP & 1.33 & 11.20 & 0.000 \\
\hline RER & 0.183 & 4.18 & 0.000 \\
\hline EXD & -0.200 & -3.38 & 0.002 \\
\hline Adj. $\mathrm{R}^{2}$ & 0.980 & F-statistics & 659.17 \\
D.W & 0.927 & Prob. & 0.000 \\
\hline
\end{tabular}

Source: Authors' Estimations

Above table -4 indicates that the GDP's long run coefficient and RER both have expected signs and are considerably vital. The EXD's long run coefficient is negative and significant, statistically. These will only be valid in the long run, if and only if, a co-integration exists. 


\subsection{Sensitivity Analysis}

Table -5: Robustness of Long run coefficients of Export by FMOLS.

\begin{tabular}{|l|l|l|l|}
\hline Variables & Coefficient & t-statistics & Prob. \\
\hline Constant & -4.322573 & -2.368032 & 0.0232 \\
\hline GDP & 1.139801 & 5.724497 & 0.0000 \\
\hline RER & 0.179324 & 1.224961 & 0.2283 \\
\hline EXD & 0.001956 & 0.613380 & 0.5434 \\
\hline Adj. R $^{2}$ & 0.976840 & \\
& & & \\
\hline
\end{tabular}

Source: Authors' Estimations

FMOLS method is used for the sensitivity analysis of the model. The outcomes of FMOLS are given in table -5.The outcomes of FMOLS discovered that the coefficients of external debt are significant and same as OLS thus it is concluded that the results from OLS are robust.

We followed Hendry's (1980) general to specific modeling approach, to study the short term relationship. We included one lag of dependent and independent variables, and one lag of error correction term in our error-correction model. At the end of the experimentation with the general form of the error correction model, the model that perfectly fits the data is reported in table -6 .

Table-6: Results of Error Correction Model

\begin{tabular}{|l|l|l|l|l|}
\hline Variable & Coefficient & Std. Error & t-Statistic & Prob. \\
\hline $\mathrm{C}$ & -0.048 & 0.038 & -1.257 & 0.217 \\
\hline $\mathrm{D}(\mathrm{EXP}(-1))$ & 0.120 & 0.154 & 0.781 & 0.439 \\
\hline $\mathrm{D}(\mathrm{GDP})$ & 1.910 & 0.779 & 2.451 & 0.019 \\
\hline $\mathrm{D}(\mathrm{RER})$ & 0.204 & 0.116 & 1.756 & 0.087 \\
\hline $\mathrm{D}(\mathrm{EXD})$ & 0.004 & 0.003 & 1.188 & 0.243 \\
\hline RESID(-1) & -0.587 & 0.167 & -3.511 & 0.001 \\
\hline Adjusted R-squared & 0.432 & F-statistic & 5.179 \\
\hline Durbin-Watson stats & 1.985 & \multicolumn{2}{|l|}{ Probability } & 0.001 \\
\hline
\end{tabular}

Source: Authors' estimation.

\subsection{Causality Analysis}

The direction of causality among export and external debt is studied by using Granger (1969) causality test. Jones (1989) supports the ad hoc selection method for lag length in Granger causality test over some of other statistical methods to find optimal lag.

Table -7: Granger causality

\begin{tabular}{|l|l|l|l|}
\hline Null Hypothesis: & Obs & F-Statistic & Prob. \\
\hline EXP does not Granger Cause EXD & 42 & 2.75278 & 0.1051 \\
\hline EXD does not Granger Cause EXP & & 4.61688 & 0.0379 \\
\hline
\end{tabular}

Source: Author's estimations.

The results show the unidirectional causality exists from EXD to export. The causality test results are reported in table -7 . 


\subsection{Impulse Response}

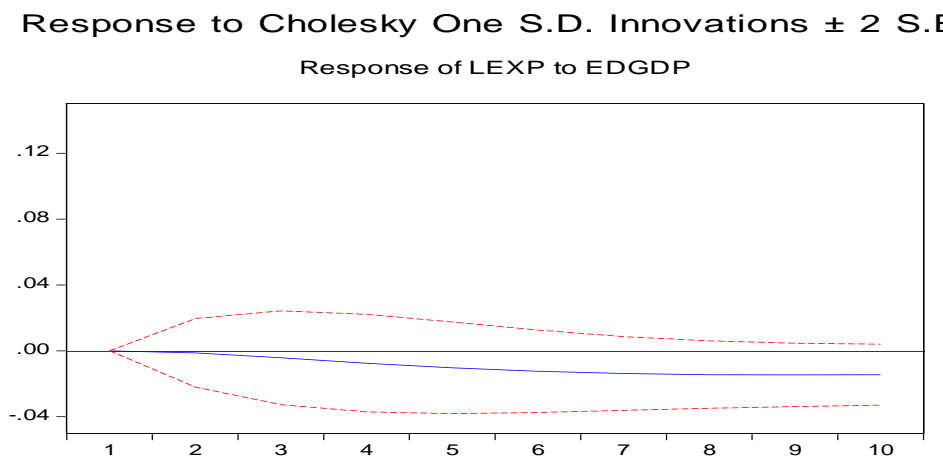

The result of impulse response also confirms the negative relationship between external debt and export in Pakistan.

\subsection{Stability Analysis}

The long run estimates are stable over the sample period, as shown in the Figure 1 and 2.

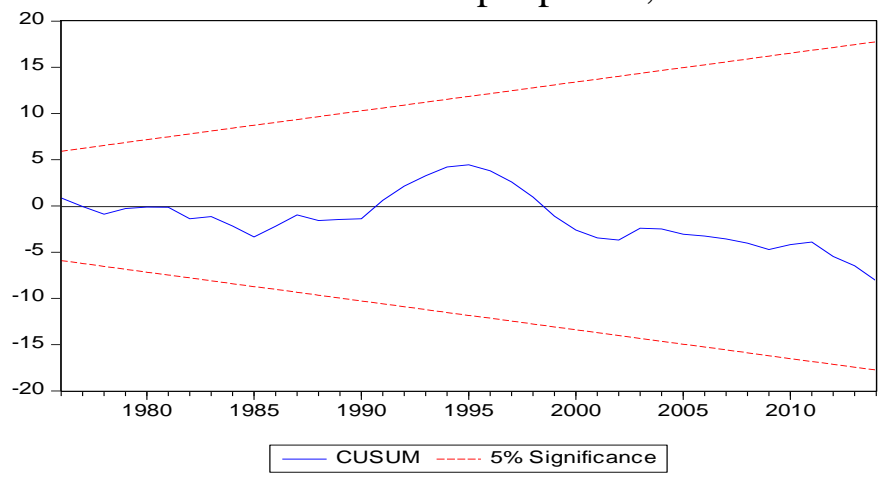

Figure .1

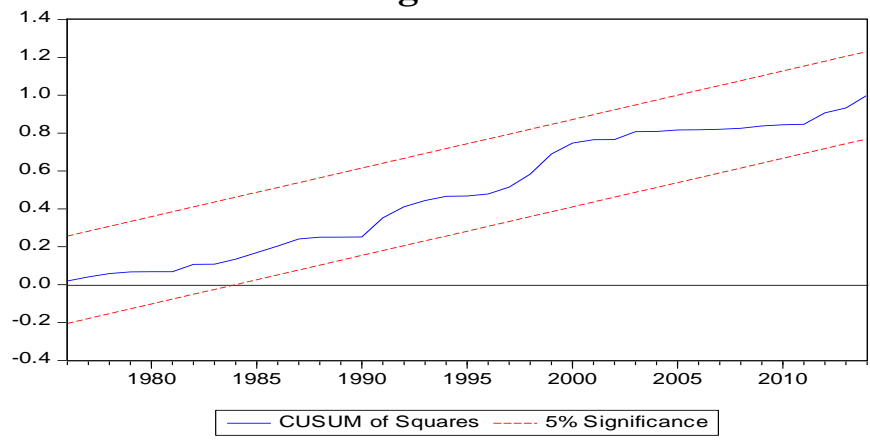

Figure .2

\section{CONCLUSION AND POLICY RECOMMENDATIONS}

In this study for stationary ADF and Phillips-Perron test were performed. The ADF test analysis disclose that all variables are non-stationary at level, and stationary at first difference while the PP-test statistics indicates that few variables are stationary at the level, therefore to justify the long-term relationship among the variables the ARDL test is valid to determine the long run relationship, To check this, co-integration analysis has been performed and it confirms significant negative long run relationship between external debt and exports performance in Pakistan. Expanding debt burden leads government to increase 
taxes that decreases after return on capital and decreases the motivation for investment. This leads decline in production and exports as well. To justify the short run relationship between the variables the Error correction techniques has been used the results indicate insignificant relationship between external debt and exports in short run. To check the stability of the coefficient throughout the sample period the CUSOM and CUSOMQ test has been performed the Coefficient Stability analysis confirms that long run model is stable. To reveal the causality between the variables the Granger causality test is done and the outcome shows unidirectional causal relationship run from external debt and exports and the result of impulse response also confirms the negative relationship between external debt and export in Pakistan.

One of the major reasons of negative relationship between external debt and export is the IMF conditionality to Pakistan that it has to raise revenue by increasing indirect taxes and increasing energy prices as a results external debt exert negative impact on export performance of Pakistan.

Government should improve the regional trade agreement and should avail the opportunity of GSP plus status by improving the law and order situation, to control the failure of power supply and Export rebate should be given especially to the Export Processing Zones. These are the preliminary measure that should be taken in order to minimize the negative impact of external debt on export performance in the country. It is also suggested that dependency on external debt should be discouraged and this gap of foreign inflow should be covered with foreign direct investment and inflows of workers' remittances in the country. These inflow will not create liability further even help to repay previous debt payment of the country. The policy makers should design effective loan protocols that will help in further evaluation of how it can be used effectively to make sure the reimbursement and to improve export performance of Pakistan.

The direction of future research is that export should be analyze at disaggregate level, so that it could be identify the effect of foreign loans on disaggregate level for policy measures.

\section{REFERENCES}

Atique, R., \& Malik, K. (2012). Impact of domestic and external debt on the economic growth of Pakistan. World Applied Sciences Journal, 20(1), 120-129.

Ali, R., \& Mustafa, U. (2012). External debt accumulation and its impact on economic growth in Pakistan. The Pakistan Development Review, 79-95.

Abdullahi, Y. Z., Aliero, H. M., \&Abdullahi, M. (2013). Analysis of the Relationship between External Debt and Economic Growth in Nigeria. Interdisciplinary Review of Economics and Management, 3(1), 1-11.

Ali, Sharafat (2014). Foreign Capital Flows and Economic Growth in Pakistan: An Empirical Analysis. World Applied Sciences Journal, 29(2), 193-201.

Ahmed, Q. M., Butt, M. S., Alam, S., \&Kazmi, A. A. (2000). Economic Growth, Export, and External Debt Causality: The Case of Asian Countries [with Comments]. The Pakistan Development Review, 591-608.

Afzal, M., urRehman, H., \&urRehman, J. (2008). Causal nexus between economic growth, export and external debt servicing: The case of Pakistan. Retrieved December, 14, 2009.

Ali, Sharafat (2014). Foreign Capital Flows and Economic Growth in Pakistan: An Empirical Analysis. World Applied Sciences Journal, 29(2), 193-201.. 
AminuUmaru, A. A. (2013). External Debt and Domestic Debt Impact on the Growth of the Nigerian Economy .External Debt and Domestic Debt Impact on the Growth of the Nigerian Economy, 1-16.

Checherita-Westphal, C., \&Rother, P. (2012). The impact of high government debt on economic growth and its channels: An empirical investigation for the euro area. European Economic Review, 56(7), 1392-1405.

Dritsaki, Chaido. "Causal nexus between economic growth, exports and government debt: the case of Greece." Procedia Economics and Finance 5 (2013): 251-259.

Gohar, M., Bhutto, N. A., \& Butt, F. (2012). The Impact of External Debt Servicing on the growth of Low-Income Countries, Sukkur Institute of Business Administration. In Proceedings of 2nd International Conference on Business Management (ISBN: 978969-9368-06-6).

Gersovitz, 1981, "Debt with Potential Repudiation: Theoretical and Empirical Analysis," Review of Economic Studies, Vol. 48, pp. 289-309.

Kasidi, F., \& Said, A. M. (2013). Impact of external debt on economic growth: A case study of Tanzania. Advances in Management and Applied Economics, 3(4), 59.

Karagol, E. (2002). The causality analysis of external debt service and GNP: The case of Turkey. Central Bank Review, 1(2), 39-64.

Kızılgöl, Ö. A., \&İpek, E.(2012) An Empirical Evaluation of the Relationship between Trade Openness and External Debt: Turkish Case.

Muhammad Afzal Lecturer, H. u. (2008, december). causal nexus between economic growth, export and external debt servicing the case of pakistan. causal nexus between economic growth, export and external debt servicing the case of pakistan , 1-15.

Panizza, U. (2008, March). Domestic and external public debt in developing countries. In United Nations Conference on Trade and Development Discussion Paper (No. 188).

QaziMasood Ahmed, M. S. (2000). Economic Growth, Export, and External Debt Causality: The Case of Asian Countries .Economic Growth, Export, and External Debt Causality: The Case of Asian Countries , pp. 1-18.

Saad, Wadad. "Causality between economic growth, export, and external debt servicing: the case of Lebanon." International Journal of Economics and Finance 4.11 (2012): 134.

Schclarek, A. (2004). Debt and Economic Growth in Developing and Industrial Countries. Debt and Economic Growth in Developing and Industrial Countries , 1-39.

Shabbir, S. (2008). Does External Debt Affect Economic Growth: Evidence from Developing Countries .Does External Debt Affect Economic Growth: Evidence from Developing Countries, pp. 1-26.

Zafar, M., Sabri, P. S. U., Ilyas, M., \&Kousar, S. (2015). the impact of trade openness and external debt on economic growth: new evidence from south asia, east asia and middle east. science international, 27(1). 